\title{
Infectious pancreatic necrosis virus (IPNV) from salmonid fish enters, but does not replicate in, mammalian cells
}

\author{
Irene Ørpetveit ${ }^{*}$, Thomas Küntziger ${ }^{2}$, Hilde Sindre ${ }^{1}$, Espen Rimstad ${ }^{3}$ and Birgit H Dannevig ${ }^{1}$
}

\begin{abstract}
Background: The aquatic birnavirus infectious pancreatic necrosis virus (IPNV) causes infectious pancreatic necrosis (IPN), a severe disease in farmed salmonid fish. IPNV has a very broad host range and infects many different species of fish as well as molluscs and crustaceans. Investigation of the host reservoir of a virus may reveal important molecular mechanisms governing the infection processes such as receptors and entry mechanisms. In the present work we have studied whether IPNV is able to infect cells with different mammalian origin.

Results: IPNV bound in a specific manner to a membrane protein of the rabbit kidney cell line RK-13 as shown by the use of a virus overlay protein binding assay (VOPBA). Six different mammalian cell lines were inoculated with IPNV and incubated in parallels at different temperatures. At 7 days post inoculation (dpi), IPNV was detected by indirect immunofluorescent antibody test (IFAT) in all the cell lines. Confocal microscopy confirmed intracellular presence of the virus. No apparent cytopathic effect (cpe) was observed in any of the cultures, and no viral replication was demonstrated with real-time RT-PCR.
\end{abstract}

Conclusion: Our results show that IPNV is able to enter into a wide range of mammalian cells, and virus entry is most likely receptor mediated. We found no indication of IPNV replication in any of the mammalian cell lines tested.

Keywords: Host susceptibility, Virus entry, Entry mechanism, Receptor, Birnaviridae, Aquabirnavirus, IPNV

\section{Introduction}

Infectious pancreatic necrosis virus (IPNV) is the etiological agent of infectious pancreatic necrosis (IPN), an important disease in the salmonid fish farming industry. The virus is icosahedral, naked, with a bisegmented dsRNA genome and belongs to genus Aquabirnavirus in the family Birnaviridae. The genus Aquabirnavirus, of which IPNV is the type species, comprises aquatic birnaviruses isolated from a large number of fish species living at different temperatures from $4^{\circ} \mathrm{C}$ to $28^{\circ} \mathrm{C}$ [1]. In addition to the genus Aquabirnavirus, the family Birnaviridae also includes the genus Avibirnavirus, type strain Infectious bursal disease virus (IBDV) infecting poultry, the genus Entomobirnavirus, type strain Drosophila $X$ virus (DXV) infecting the fruit fly (Drosophila melanogaster)

\footnotetext{
* Correspondence: irene.orpetveit@vetinst.no

${ }^{1}$ Norwegian Veterinary Institute, P.O. Box 0750, Sentrum, Oslo, NO 0106, Norway

Full list of author information is available at the end of the article
}

[1] and the recently added genus Blosnavirus, type strain Blotched snakehead virus (BSNV) [2].

The host range of aquatic birnaviruses is not restricted to fish, as viruses from this genus have also been isolated from shrimps [3], crustaceans and molluscs [4]. IPNV replicates in cell lines derived from a wide range of freshwater and marine hosts [5], and even in cell lines derived from green turtles [6]. While IPNV propagation in cell culture is shown to have an upper temperature limit of $28^{\circ} \mathrm{C}$ [7], the RNA dependent RNA polymerase ( $\left.\mathrm{RdRp}\right)$ is active at $37^{\circ} \mathrm{C}$ as assessed by in vitro RNA synthesis experiments [8]. The virus is temperature resistant, and retains infectivity even after one hour at $60^{\circ} \mathrm{C}$ in fish silage [9].

To our knowledge, IPNV is not reported to replicate in cell lines derived from homeothermic animals or insects. This may be attributed to properties of either the host or the virus or of both. The fish virus betanodavirus Red grouper nervous necrosis virus (RGNNV) was shown to bind to human cells in cell culture, but was unable to

\section{Biomed Central}


enter into these cells. However, virus replication could be initiated by transfection of cells with viral RNA [10].

Knowledge of possible virus host reservoirs is important for understanding the infection mechanisms of the viruses, such as viral receptors, entry mechanisms and temperature limits for viral replication. We have investigated whether IPNV can adsorb to, enter into and replicate in mammalian cell lines.

\section{Materials and methods \\ Cells and virus}

The piscine and mammalian cell lines applied are listed in Table 1. Chinook salmon embryo (CHSE)-214 cells are piscine cells susceptible to IPNV, and CHSE-214 is one of the preferred cell lines for isolation and propagation of the virus. The mammalian cell lines used were rabbit kidney (RK)-13 cells, foetal bovine turbinate (FBT) cells, monkey kidney epithelial Vero cells, primary human embryonic fibroblasts (HE cells), human lung carcinoma cells (A549) and human leukemic monocytes (THP-1 cells).

Two IPNV preparations were applied: a first passage virus supernatant (IPNV-1p) and purified IPNV (IPNVpur). Kidney tissue from an experimentally IPNV infected Atlantic salmon (Salmo salar L.) (IPNV serotype Sp, a kind gift from VESO-Vikan, Norway) was homogenized in T10 (Table 1) and cleared by low speed centrifugation. This tissue supernatant was passaged once in BF-2 cells, and the resulting cell supernatant is referred to as IPNV-1p. IPNV-pur was prepared from IPNV-1p by CsCl density-gradient centrifugation as previously described [11]. The virus preparations were aliquoted and stored at $-80^{\circ} \mathrm{C}$ until use.

Virus titration was performed by end-point dilution as described [11], and TCID50 $\mathrm{ml}^{-1}$ was determined according to Kärber (1931) [12].

Prior to virus inoculation, all cells were grown to 70-80\% confluence. Cell culture medium without FBS was used as virus dilution medium to obtain the desired titres. After virus adsorption for $1 \mathrm{~h}$ at $37^{\circ} \mathrm{C}$, the cells were incubated at $15^{\circ} \mathrm{C}, 25^{\circ} \mathrm{C}$ or at $37^{\circ} \mathrm{C}$ until harvesting/fixation.

\section{Virus overlay protein binding assay (VOPBA)}

Membrane proteins were extracted from cells as previously described [11]. Binding of IPNV to membrane proteins from RK-13 (Table 1), was studied by VOPBA as previously described [11]. A fraction of CHSE-214 (Table 1) membrane proteins was included as positive control. In brief, approximately $20 \mu \mathrm{g}$ of membrane proteins extracted from the respective cell lines were separated by SDS-PAGE and transferred to a $0.45-\mu \mathrm{m}$ nitrocellulose membrane (blot) using the Criterion Precast Gel System (Bio-Rad). After blocking, the blot was incubated for $2 \mathrm{~h}$ at room temperature with IPNVpur (final titre $>10^{6} \mathrm{TCID}_{50} \mathrm{ml}^{-1}$ ). Bound virus was detected with a monoclonal antibody against virus protein (VP)-3 (anti-VP3) (IPN-VP3-C12, Intervet Norbio, Bergen, Norway) and a HRP-conjugated sheep anti-mouse Ig (Amersham Biosciences, Bucks, UK) as secondary antibody. Negative control blots were prepared similarly, except that IPNV-pur was replaced with PBS. To verify the reactivity of the primary antibody against the virus protein, IPNV proteins were included in the SDS-PAGE.

\section{Examination of inoculated cell cultures \\ Indirect immunofluorescence test (IFAT)}

Mammalian cells (Table 1) were grown in 96-well strip plates (Corning ${ }^{\circledR}$ Costar $^{\circledR}$, Corning, NY). Each well contained $150 \mu \mathrm{l}$ of cell culture medium, into which $50 \mu \mathrm{l}$ of IPNV-pur $\left(10^{6} \mathrm{TCID}_{50} \mathrm{ml}^{-1}\right)$ was added. Parallel plates with each cell culture were incubated for one week at $15^{\circ} \mathrm{C}$, $25^{\circ} \mathrm{C}$ and $37^{\circ} \mathrm{C}$, respectively. Cells were fixed with $80 \%$ acetone and probed with monoclonal primary antibodies against virus protein (VP) 2 (anti-VP2) (1:50, anti-VP2 N1-H8, Intervet Norbio, Bergen, Norway), or against virus protein (VP) 3 (anti-VP3) (1:50). As secondary antibody, we applied FITC-conjugated anti-mouse-Ig (1:100, SouthernBiotech, Birmingham, AL 35209 USA). Nuclei were

Table 1 Cell lines

\begin{tabular}{|c|c|}
\hline Cell lines & Growth media $^{(*)}$ \\
\hline Chinook salmon embryo cells (CHSE)-214 (Fryer et al., 1965) & Ørpetveit et al., 2008 \\
\hline Rabbit kidney (RK)-13 cells (ATCC CCL-37) & $\begin{array}{l}\text { MEM Eagle's with Earle's BSS (EMEM) supplemented with 10\% FBS, } \\
4 \mathrm{mM} \text { L-glutamine and } 50 \mu \mathrm{g} / \mathrm{ml} \text { gentamicin, final } \mathrm{pH} 7.6\end{array}$ \\
\hline Foetal bovine turbinate (FBT) cells ("in house" cell line) & $\begin{array}{l}\text { As described for RK-13 cells, but supplemented with } 16.4 \text { mM Tris-buffer } \\
(\mathrm{pH} 7,8) \text { and } 5.3 \mathrm{mM} \mathrm{NaHCO}_{3} \text {, final } \mathrm{pH} 7.6\end{array}$ \\
\hline Vero cells ATCC CCL-81 ${ }^{\mathrm{TM}}$ & \multirow{4}{*}{$\begin{array}{l}\text { RPMI-1640 (Sigma-Aldrich, St Louis, MO) supplemented with 10\% FBS and } \\
50 \mu \mathrm{g} / \mathrm{ml} \text { gentamicin. }\end{array}$} \\
\hline $\begin{array}{l}\text { Primary human embryonic fibroblast (HE) cells (a kind gift from } \\
\text { Rikshospitalet University Hospital, Oslo, Norway) }\end{array}$ & \\
\hline A549 cells (human) (ATCC CCL-185 $5^{\mathrm{TM}}$ ) & \\
\hline THP-1 cells (human) (ATCC TIB-202 ${ }^{\mathrm{TM}}$ ) & \\
\hline
\end{tabular}

(*) Where not otherwise indicated, the cell culture reagents were obtained from Cambrex Bio Science, Rockland, ME. 
stained with $10 \mu \mathrm{g} / \mathrm{ml}$ propidium iodine (Sigma). Fluorescence images were acquired on a Leica DM IL inverted phase contrast microscope (Leica Microsystems Wetzlar GmbH, Wetzlar, Germany) equipped with a 40X/0.5 objective and a Nikon DXM1200F digital camera.

\section{Confocal microscopy}

RK-13 and Vero cells were grown on glass cover slips in 24-well plates (Corning ${ }^{\circledR}$ Costar $^{\circledR}$, Corning, NY) and inoculated with IPNV-pur $\left(10^{6} \mathrm{TCID}_{50} \mathrm{ml}^{-1}\right)$, followed by incubation at $37^{\circ} \mathrm{C}$ for $24 \mathrm{~h}$. Paraformaldehyde fixation and permeabilization with $0.1 \%$ Triton X-100 was performed as described [13], and cells were probed with anti-VP2 (1:50) followed by DyLight 488 secondary antibodies (1:500; Jackson lmmunoResearch West Grove, PA USA). Nuclei were stained with $0.25 \mathrm{mg} / \mathrm{ml}$ DAPI (Sigma). Confocal images were acquired on an Olympus FluoView 1000 inverted microscope equipped with a Super Apochromat 60X/1.35 oil objective.

\section{Real-time reverse transcription-polymerase chain reaction (RRT-PCR)}

Vero and HE cells grown in $25-\mathrm{cm}^{2}$ culture flasks were inoculated with IPNV-1p (final virus titre $10^{4}$ $\operatorname{TCID}_{50} \mathrm{ml}^{-1}$ ). After adsorbtion at $37^{\circ} \mathrm{C}$ for 1 hour, the inoculum was replaced with fresh medium, and the cells were further incubated in parallels at $25^{\circ} \mathrm{C}$ and $37^{\circ} \mathrm{C}$. At 7, 14, 21 and 27 days post inoculation (dpi), the cells at $37^{\circ} \mathrm{C}$ were passaged with cocultivation (1:1) with uninfected cells. Cells incubated at $25^{\circ} \mathrm{C}$ were not passaged due to poor growth after 7 days. At different time points, the cells were investigated for cytopathic effect (cpe), and cell medium from both cell lines was harvested and stored at $-80^{\circ} \mathrm{C}$ until virus titration. The cell monolayers were washed twice with $2 \mathrm{ml}$ PBS, following the addition of 1.5 ml of NucliSens ${ }^{\circledR}$ easyMAG ${ }^{\mathrm{TM}}$ lysis buffer (bioMérieux, Boxtel, The Netherlands). Nucleic acid extraction was performed with the NucliSens ${ }^{\circledR}$ easyMAG ${ }^{\mathrm{TM}}$ (bioMerieux Inc.) according to the manufacturer's instruction for the off-board protocol. Nucleic acid concentrations were determined using a NanoDrop ND-1000 (NanoDrop Technologies, Wilmington, Delaware USA), and the RRT-PCR was performed in duplicates as described [14] with $250 \mathrm{ng} / \mu \mathrm{l}$ of nucleic acids in each reaction.

\section{Results}

VOPBA showed that IPNV interacted in a specific manner with a membrane protein from the mammalian RK-13 cells migrating at approximately $85 \mathrm{kDa}$ (Figure 1). Specific binding was also detected between IPNV and membrane proteins from CHSE-214 salmon embryo cells, with a reactive band at $220 \mathrm{kDa}$, as previously shown [11]. No bands were observed when IPNV-pur

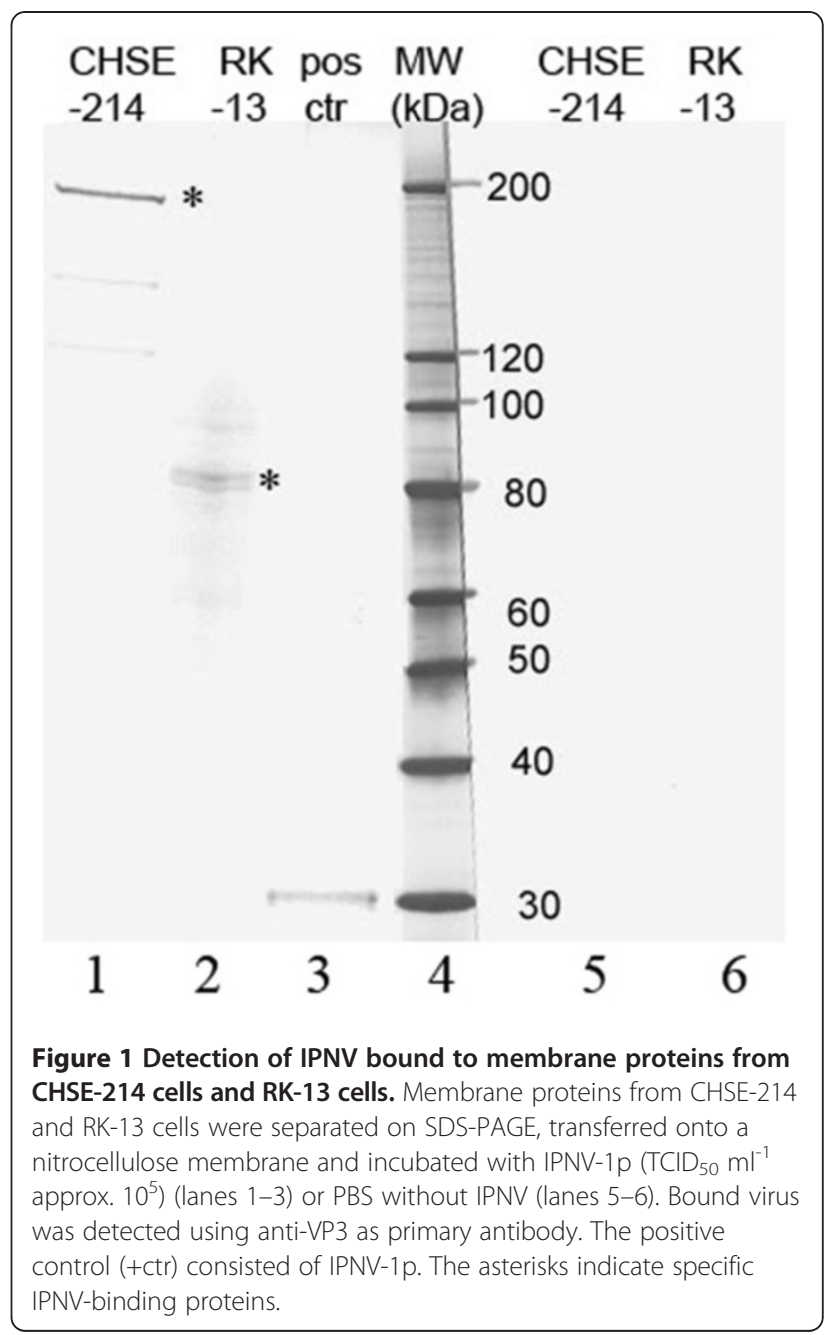

was replaced with PBS (Figure 1). A band corresponding in size with VP3 appeared in the lane with the positive control virus, thus verifying the reactivity of the primary antibody (Figure 1).

RK-13, FBT, Vero, HE, AK549 and THP-1 cells (Table 1) were inoculated with IPNV in 96-well plates and incubated in parallels at different temperatures. The cells were examined for cpe at $7 \mathrm{dpi}$ and subsequently immunostained. Cells kept at $15^{\circ} \mathrm{C}$ and $25^{\circ} \mathrm{C}$ were in poor condition, but still attached to the surface, while the cells kept at $37^{\circ} \mathrm{C}$ had grown to confluence. Positive staining for IPNV was detected in all the investigated cell lines, regardless of incubation temperature (not shown). No IPNV positive fluorescence was seen in uninfected cells (not shown). Despite the high virus titres applied, no apparent cpe was observed in any of these cultures.

Confocal microscope analysis confirmed the presence of IPNV in both RK-13 and Vero cells (Figure 2). The virus was detected in the cytoplasm in discrete, punctate structures over a faint cytoplasmic background, but not attached to the outside of the plasma membrane. This 


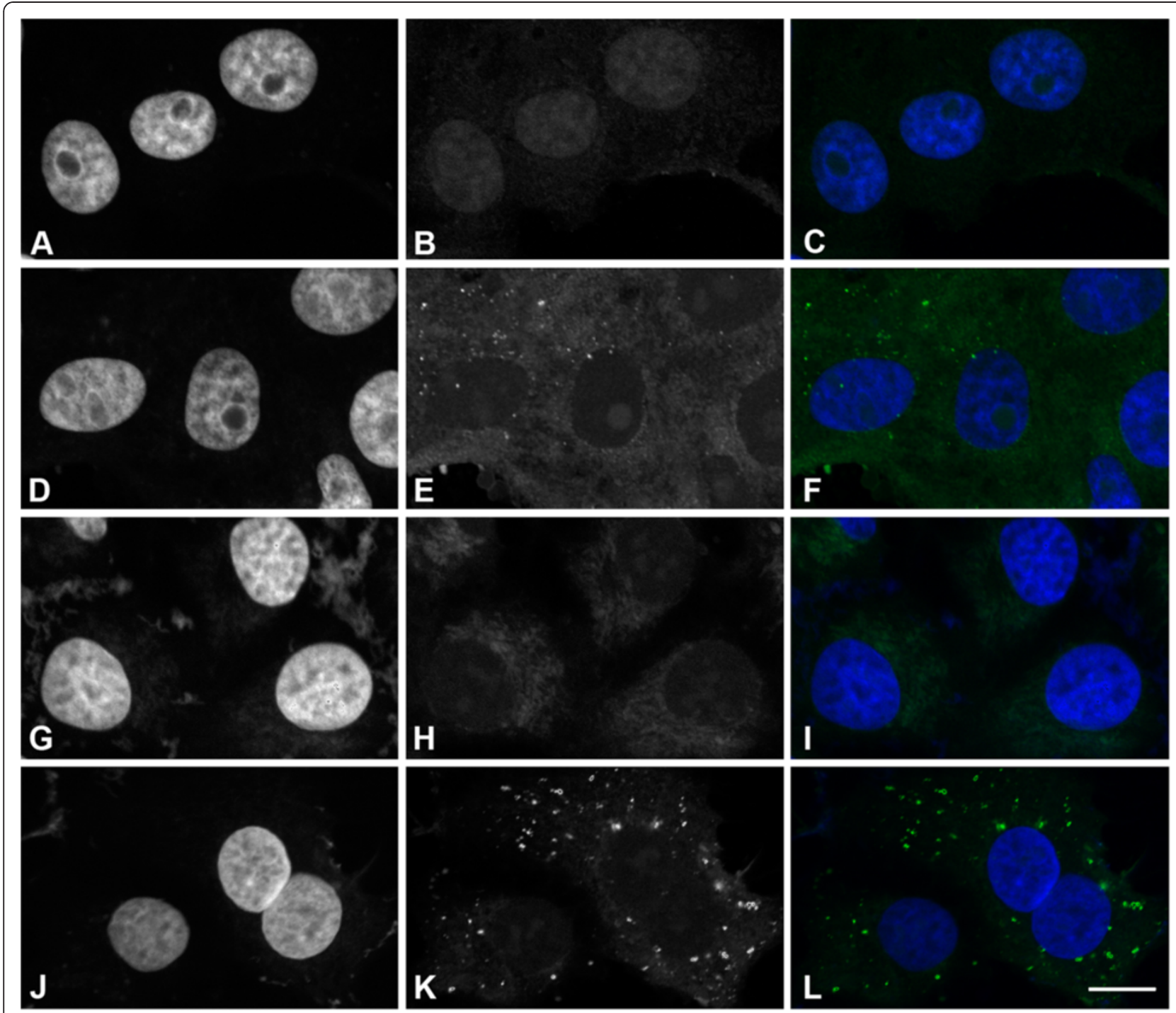

Figure 2 Confocal microscopy of mammalian cell lines inoculated with IPNV. Localization of IPNV in Vero (A-F) and RK-13 (G-L) cells that were uninfected ( $A-C$ and $G-I)$ or IPNV infected (D-F and J-L). Cells were immunolabeled with anti-VP2 (B, E, H, K) and nuclei counterstained with $\operatorname{DAPI}(A, D, G, J)$. Merged pictures are shown (C, F, I, L). Bar: $10 \mu \mathrm{m}$.

punctate staining, which was observed in approximately $100 \%$ of the infected RK13 cells and in $10-20 \%$ of the infected Vero cells, was not found in uninfected cells, where only cytoplasmic background could be observed.

To investigate whether IPNV replicates in the mammalian cell lines, the amount of viral RNA was followed in infected cell lines over several days and passages. Independent of incubation temperature, the $\mathrm{Ct}$ values obtained were relatively stable between 1-5 dpi in the infected Vero cells (Figure 3a) and HE cells (Figure 3b). The $\mathrm{Ct}$ values indicate a reduction in the IPNV RNA level between each cell passage of Vero cells (Figure 3c) and HE cells (Figure 3d). Taken together, the results indicate no or only very low levels of IPNV replication in Vero and HE cells. Microscopic examination of the cells prior to the immunolabelling revealed no cpe, and the virus was not detected in supernatant by titration.

\section{Discussion}

The host range of IPNV is very broad, and the virus has been isolated from a wide range of aquatic organisms. The virus also replicates in a variety of piscine cell lines. Other birnaviruses show a more restricted host range both in vivo and in vitro. IBDV, for instance, is only known to infect poultry and replicates in vitro in a few avian primary cell cultures [15], although the virus replicates in several cell lines of mammalian origin $[16,17]$. The entomobirnavirus DXV most likely also has a narrow host range, as it is thus far only isolated from fruit fly [18]. This indicates that there are important 


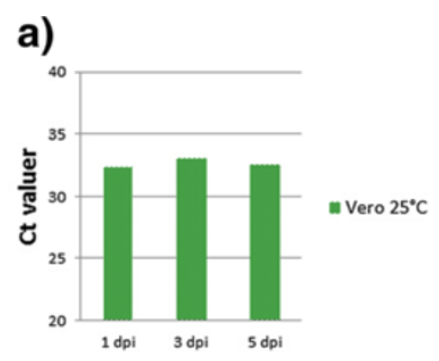

c)

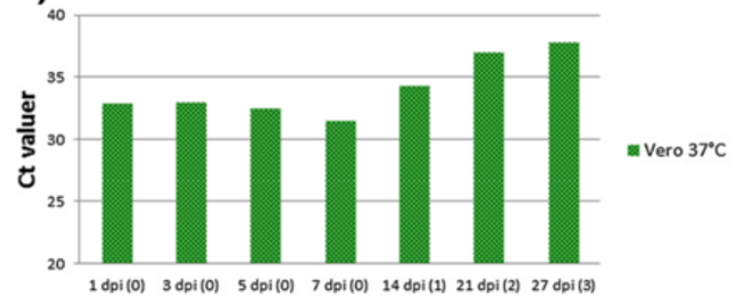

b)

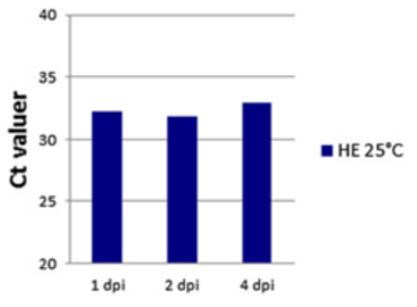

d)

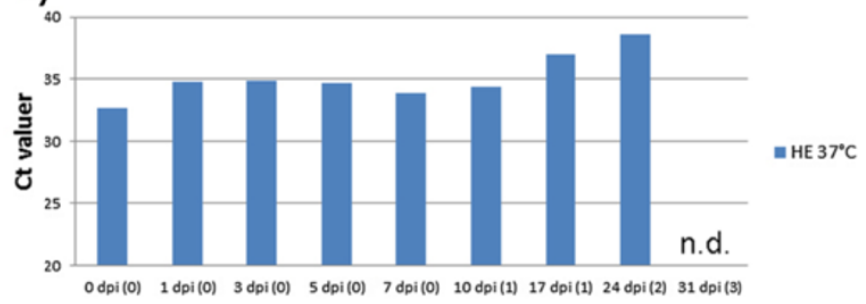

Figure 3 Detection of IPNV RNA in Vero and HE cells inoculated with IPNV. Cell culture flasks with Vero cells or HE cells were inoculated with IPNV-1p $\left(T_{C I D} \mathrm{ml}^{-1} 10^{4}\right)$ and incubated in parallels at $25^{\circ} \mathrm{C}(\mathbf{a}$ and $\mathbf{b})$ and $37^{\circ} \mathrm{C}(\mathbf{c}$ and $\mathbf{d})$. At the indicated time points, cell monolayers were harvested, nucleic acids extracted, and IPNV RNA detected by RRT-PCR. After one week of incubation, the cells kept at $37^{\circ} \mathrm{C}$ were passaged onto new flasks and cocultivated (1:1) with noninfected cells. The numbers in parenthesis indicate the passage number. The $\mathrm{Ct}$ value is an average of duplicates and $n=1$. n.d.=not detected.

differences in the molecular mechanisms governing the infection processes of these birnaviruses. Investigating the IPNV host range could reveal some of these mechanisms.

Six cell lines of human, leporid, monkey or bovine origin were inoculated with IPNV and investigated by IFAT. Virus specific staining was detected in all cell lines after incubation at $15^{\circ} \mathrm{C}, 25^{\circ} \mathrm{C}$ and $37^{\circ} \mathrm{C}$. IFAT does not distinguish between internalized or surface associated virus. Confocal microscopy analysis was therefore performed on IPNV infected HE and Vero cells. This clearly demonstrated that IPNV was present in the cytoplasm in punctate structures not associated with the plasma membrane. These structures may represent cytoplasmic structures such as endosomes or caveolae [19]. In addition, VOPBA showed that IPNV bound in a specific manner to a membrane protein of approximately $85 \mathrm{kDa}$ from RK-13 cells. Taken together, these findings indicate that IPNV is able to enter into these cells by specific endocytic mechanisms. The difference in molecular size between the IPNV binding proteins from piscine cells and the rabbit cell line could indicate that IPNV attaches to different receptors, and may even represent different entry mechanisms. This, in turn, could explain the broad host range of IPNV.

An early step in viral replication is the production of viral mRNA. IPNV mRNA lacks a poly-A tail, making discrimination between viral genomic RNA and mRNA difficult by PCR. A significant increase in viral RNA over time would, however, indicate that replication has taken place. Thus, the cell cultures were inoculated with low titres of IPNV, and viral RNA levels were detected by RRT-PCR over time. The amount of target nucleic acids was identical in each reaction, and a good correlation was found between the two parallels that were run in the RRT-PCR. Therefore, the Ct values could be used as an indicator of the relative amount of IPNV specific RNA. No significant change in the IPNV RNA level was observed at 5 dpi in HE and Vero cells. As the cells did not grow well at $25^{\circ} \mathrm{C}$, incubation at this temperature was terminated at $5 \mathrm{dpi}$. When the cells were kept at $37^{\circ} \mathrm{C}$, on the other hand, they grew to confluence within $7 \mathrm{dpi}$. No cpe was observed in any of the cell cultures at $7 \mathrm{dpi}$, even after inoculation with high levels of IPNV. We therefore did not expect any virus in the cell supernatants when inoculating cells with low levels of IPNV. Instead of passaging the virus medium onto fresh cultures, the infected cells cultures were passaged with co-cultivation. For each cell passage, we observed a decrease in the viral RNA levels, most likely due to a dilution of the RNA with each passage. This indicates that no significant level of replication occurs in these cell lines. The gradual decrease in IPNV RNA observed after 2 weeks and longer incubation suggests that the virus multiplication process is arrested before replication of viral nucleic acid starts. Even though the $\mathrm{RdRp}$ has been shown to be active at $37^{\circ} \mathrm{C}$ [8], other factors, such as structural differences between piscine and mammalian proteins or antiviral activity in the mammalian cells, 
could explain the absence of IPNV replication. The virus may also simply be trapped in the punctate structures described above. When studying RGNNV infection in human cell cultures, Adachi et al. (2008) [10] showed that circumventing some obstacles early in the infection process may lead to the production of progeny RGNNV.

\section{Conclusion}

In conclusion, we have shown that IPNV is able to enter into a wide range of different mammalian cells, and virus entry is most likely receptor mediated. We found no indication of IPNV replication in any of the mammalian cell lines tested.

\section{Abbreviations}

IPNV: Infectious pancreatic necrosis virus; IPN: Infectious pancreatic necrosis; VOPBA: Virus overlay protein binding assay; Dpi: Days post inoculation; IFAT: Indirect immunofluorescent antibody test; Cpe: Cytopathogen effect: IBDV: Infectious bursal disease virus; DXV: Drosophila X virus; BSNV: Blotched snakehead virus; RdRp: RNA dependent RNA polymerase; RGNNV: Red grouper nervous necrosis virus; CHSE: Chinook salmon embryo; RK: Rabbit kidney; FBT: Foetal bovine turbinate; HE: Human embryonic fibroblasts; FBS: Fetal bovine serum; VP: Virus protein; RRT-PCR: Real-time reverse transcription-polymerase chain reaction.

\section{Competing interests}

The authors declare that there are no competing interests.

\section{Authors' contributions}

$\varnothing$ conceived the study, contributed to the experimental design, prepared all the virus suspensions and cell membrane protein suspensions, did the cell culture work, VOPBA, RRT-PCR, IFAT, epifluorescence microscopy and image processing, contributed to discussion of the results and drafted the manuscript. TK contributed to the experimental design, did the immunofluorescence, laser confocal microscopy and image processing, and contributed in writing of the manuscript. HS and BD contributed to the experimental design, interpretation of the results and critical reading and revision of the manuscript. ER contributed with discussion of the results and critical reading and revision of the manuscript. All authors read and approved the final manuscript.

\section{Acknowledgments}

The skilled technical assistance of Inger Böckerman at the Norwegian Veterinary Institute is gratefully acknowledged. This study was supported by grant 143286/140 from the Research Council of Norway.

\section{Author details}

${ }^{1}$ Norwegian Veterinary Institute, P.O. Box 0750, Sentrum, Oslo, NO 0106, Norway. ${ }^{2}$ Institute of Basic Medical Sciences, Faculty of Medicine, University of Oslo, Box 1110Blindern, Oslo, NO 0317, Norway. ${ }^{3}$ Department of Food Safety and Infection Biology, Norwegian School of Veterinary Science, Box 8146, Dep, Oslo, NO 0033, Norway.

Received: 25 January 2012 Accepted: 3 October 2012 Published: 5 October 2012

\section{References}

1. Fauquet CM, Mayo MA, Maniloff J, Desselberger U, Ball LA: Virus Taxonomy: Eighth Report of the International Committee on Taxonomy of Viruses. San Diego, CA: Elsevier Academic Press; 2005.

2. King AMQ, Lefkowitz E, Adams M, Carstens EB: Virus Taxonomy: Ninth Report of the International Committee on Taxonomy of Viruses. London: Academic; 2011.

3. Bovo G, Ceschia C, Giorgetti G, Vanelli M: Isolation of an IPN-like virus from adult Kuruma shrimp (Penaeus japonicus). Bull Eur Ass Fish Pathol 1984, $4: 21$.
4. Rodriguez Saint-Jean S, Borrego JJ, Perez-Prieto SI: Infectious pancreatic necrosis virus: biology, pathogenesis, and diagnostic methods. Adv Virus Res 2003, 62:113-165.

5. Dobos P: The molecular biology of infectious pancreatic necrosis virus (IPNV). Ann Rev Fish Dis 1995, 5:25-54.

6. Lu Y, Nerurkar VR, Aguirre AA, Work TM, Balazs GH, Yanagihara R: Establishment and characterization of 13 cell lines from a green turtle (Chelonia mydas) with fibropapillomas. In Vitro Cell Dev Biol Anim 1999, 35:389-393.

7. Roberts TE, Dobos P: Studies on the mechanism of temperature sensitivity of infectious pancreatic necrosis virus replication. J Gen Virol 1983, 64(Pt 2):331-339.

8. Mertens PP, Jamieson PB, Dobos P: In vitro RNA synthesis by infectious pancreatic necrosis virus-associated RNA polymerase. J Gen Virol 1982, 59:47-56.

9. Whipple MJ, Rohovec JS: The effect of heat and low pH on selected viral and bacterial fish pathogens. Agriculture 1994, 123:179-189.

10. Adachi K, Ichinose T, Watanabe K, Kitazato K, Kobayashi N: Potential for the replication of the betanodavirus redspotted grouper nervous necrosis virus in human cell lines. Arch Virol 2008, 153:15-24.

11. Ørpetveit I, Gjøen T, Sindre H, Dannevig BH: Binding of infectious pancreatic necrosis virus (IPNV) to membrane proteins from different fish cell lines. Arch Virol 2008, 153:485-493.

12. Kärber G: Beitrag zur kollektiven Behandlung pharmakologischer Reihenversuch. Arch Exp Pathol Pharmakol 1931, 162:480-483.

13. Rogne $M$, Landsverk HB, Van EA, Beullens M, Bollen M, Collas $P$, et al: The $\mathrm{KH}$-Tudor domain of a-kinase anchoring protein 149 mediates RNA-dependent self-association. Biochemistry 2006, 45:14980-14989.

14. Ørpetveit I, Mikalsen AB, Sindre H, Evensen $\varnothing$, Dannevig BH, Midtlyng PJ: Detection of infectious pancreatic necrosis virus in subclinically infected Atlantic salmon by virus isolation in cell culture or real-time reverse transcription polymerase chain reaction: influence of sample preservation and storage. J Vet Diagn Invest 2010, 22:886-895.

15. Cho BR, Raymond RG, Hill RW: Growth of infectious bursal disease virus with plaque formation in chick embryo fibroblast cell culture. Avian Dis 1979, 23:209-218.

16. Kibenge FS, McKenna PK: Isolation and propagation of infectious bursal disease virus using the ovine kidney continuous cell line. Avian Dis 1992, 36:256-261.

17. Tham KM, Moon CD: Apoptosis in cell cultures induced by infectious bursal disease virus following in vitro infection. Avian Dis 1996, 40:109-113.

18. Teninges D, Ohanessian A, Richard-Molard C, Contamine D: Isolation and biological properties of Drosophila X virus. J Gen Virol 1979, 42:241-254.

19. Sieczkarski $S B$, Whittaker GR: Dissecting virus entry via endocytosis. J Gen Virol 2002, 83:1535-1545.

doi:10.1186/1743-422X-9-228

Cite this article as: Ørpetveit et al:: Infectious pancreatic necrosis virus (IPNV) from salmonid fish enters, but does not replicate in, mammalian cells. Virology Journal 2012 9:228.

\section{Submit your next manuscript to BioMed Central and take full advantage of:}

- Convenient online submission

- Thorough peer review

- No space constraints or color figure charges

- Immediate publication on acceptance

- Inclusion in PubMed, CAS, Scopus and Google Scholar

- Research which is freely available for redistribution 